\title{
Avaliação da flutuação populacional epifítica de Pseudomonas marginalis pv. marginalis e sua relação com a severidade da queima- bacteriana do alho
}

\author{
Evaluation of epiphytic population floating of Pseudomonas marginalis pv. marginalis and \\ relationship with the severity of bacterial blight of garlic
}

Leandro Luiz Marcuzzo (ORCIC 0000-0002-0114-1185), Graziele Andressa Catafesta (ORCID 0000-0003-3381-6594)

Instituto Federal Catarinense, Rio do Sul, SC Brasil. *Autor para correspondência: leandro.marcuzzo@ifc.edu.br

Submissão: 15/12/2020 / Aceite: 05/08/2021

\begin{abstract}
RESUMO
A cultura do alho é afetada pela queima-bacteriana causada por Pseudomomas marginalis pv. marginalis (Pmm). Com o objetivo de avaliar a relação da flutuação populacional epifítica de Pmm com a severidade da doença, bulbilhos do cultivar "Chonan" foram inoculados com a bactéria diferenciadora mutante a rifampicina $\left(\mathrm{Pmm}^{\text {rf }}\right.$ ) e semeados a campo. A severidade foi avaliada semanalmente em 100 plantas ao acaso e a população epifítica de $\mathrm{Pmm}^{\text {rf }}$ das folhas foi diluída em série e depositada em meio de cultura com rifampicina. Após a incubação a $28^{\circ} \mathrm{C}$ por 48 horas, as colônias de $\mathrm{Pmm}{ }^{\text {rf }}$ foram contadas. Os dados foram submetidos à correlação de Pearson e avaliada a sua significância pelo teste. A severidade da doença e a população epif́tica iniciaram a partir da sétima semana. A severidade final atingiu 67 e $74 \%$ no ciclo de 2019 e 2020 respectivamente. A população epifítica quando atingiu a ordem de $10^{5}$ e $10^{6} \mathrm{em}$ cada ano, manteve-se estável até o final do ciclo da cultura. A correlação foi de 0,688 e 0,521 para cada ano, indicando uma correlação moderada e significativa entre a severidade da doença e a população bacteriana. Este trabalho servirá de base epidemiológica e para elaboração de um sistema de previsão para manejo da doença na cultura.
\end{abstract}

PALAVRAS-CHAVE: Allium sativum, bactéria, epidemiologia, viabilidade de inóculo.

\begin{abstract}
The garlic crop is affected by the bacterial blight caused by Pseudomomas marginalis pv. marginalis (Pmm). Here, we evaluate the relationship between the epiphytic population fluctuation of Pmm and the severity of the disease. Cloves of the "Chonan" cultivar were inoculated with the mutant differentiating bacteria rifampicin $\left(P m m^{\text {rf }}\right)$. After, they were then sown in the field. The severity was evaluated weekly over 100 random plants and the epiphytic population of $\mathrm{Pmm}^{\text {rf }}$ from the leaves was serially diluted and deposited in culture medium containing rifampicin. After incubation at $28^{\circ} \mathrm{C}$ for 48 hours, $\mathrm{Pmm}^{\text {tf }}$ colonies were counted. The data were submitted to Pearson's correlation, and its significance was also evaluated. The severity of the disease and the epiphytic population started from the seventh week. The final severity reached 67 and $74 \%$ in the 2019 and 2020 cycles, respectively. However, when the epiphytic population reached $10^{5}$ and $10^{6}$ each year, it remained stable until the end of the culture cycle. The Pearson's correlation achieves the 0.688 and 0.521 scores for both selected periods, indicating a moderate and significant correlation between the severity of the disease and the bacterial population. This research helps to elaborate epidemiological protocols and for the elaboration of forecasting systems.
\end{abstract}

KEYWORDS: Allium sativum, bacteria, epidemiology, inoculum viability.

Dentre as doenças foliares que atacam a cultura do alho (Allium sativum L.) e reduzem o seu potencial produtivo, a principal é a queima-bacteriana causada por Pseudomonas marginalis pv. marginalis (Brown) Stevens (sin. P. fluorescens biovar II) (BECKER 2004).

Os sintomas podem ocorrer durante todo o desenvolvimento da cultura, onde primeiramente as folhas apresentam uma descoloração da clorofila e posteriormente a formação de estrias amarelas e longas, e com o aumento da intensidade da doença, acaba ocorrendo encharcamento de cor amarronzada e amolecimento na nervura central (MARCUZZO 2018, SOUZA 2009). O resto do limbo pode permanecer sadio, porém, mas 
acaba ocupando toda a folha e no posteriormente no final, uma tonalidade marrom e seca semelhante a maturação fisiológica da planta (BECKER 1991). Os sintomas podem evoluir para o pseudocaule e ao bulbo, onde pode ocorrer podridão (LOPES \& QUEZADO-SOARES 1997). Entre as características de identificação dessa bactéria em laboratório é da emissão de fluorescência em luz negra quando cultivada em meio de cultura King-B (MARCUZZO \& AMLER 2020, MOURA \& ROMEIRO 1997, ROMEIRO 1995).

Atualmente não há cultivares resistentes para essa doença, e, por isso, o seu controle vem sendo feito com pulverizações frequentes de fungicidas a base de cobre (BECKER 1991). Uma das maneiras de reduzir o uso de fungicidas cúpricos e manejar a doença é conhecer quais as condições que favorecem a ocorrência da doença, que envolvem o ambiente, o patógeno e o hospedeiro (MARCUZZO \& FÜCHTER 2021ab, BERGAMIM FILHO \& AMORIM 2011). Em relação ao patógeno, o detalhamento da flutuação populacional epifítica de células bacterianas da $P$. marginalis pv. marginalis na superfície foliar em área de cultivo constituise em uma informação importante no avanço do manejo fitossanitário (MARCUZZO \& SANTOS 2021 , JARDINE \& STEPHENS 1987).

Diante do exposto, este trabalho teve por objetivo avaliar a flutuação de células bacteriana de $P$. marginalis pv. marginalis presente do filoplano foliar em área de cultivo de alho e a sua relação com severidade da queima-bacteriana-do-alho nos anos de 2019 e 2020.

O trabalho foi conduzido no Instituto Federal Catarinense - IFC/Campus Rio do Sul, no município de Rio do Sul - SC, (Latitude: 2711'07' S e Longitude: 49³9'39' W, altitude 655 metros acima do nível do mar) durante o período de 14 de junho a 15 de novembro de 2019 (Ciclo 2019) e de 15 de junho a 16 de novembro de 2020 (Ciclo 2020).

Segundo a classificação de Köppen, o clima local é subtropical úmido ( $\mathrm{Cfa}$ ) e solo classificado como Cambissolo Háplico Tb distrófico (EMBRAPA 2013) com os seguintes atributos químicos: pH em água de 6,0; teores de $\mathrm{Ca}^{+2}, \mathrm{Mg}^{+2}, \mathrm{Al}^{+3}$ e CTC de 4,2; 1,8; 0,0 e 9,54 cmolc. $\mathrm{dm}^{-3}$, respectivamente; saturação por bases de $66,49 \%$, teor de argila de $30 \% \mathrm{~m} / \mathrm{v}$ e teores de $\mathrm{P}$ e $\mathrm{K}$ de 14 e $134 \mathrm{mg} \cdot \mathrm{dm}^{-3}$, respectivamente.

Os dados meteorológicos foram obtidos de uma estação Davis ${ }^{\circledR}$ Vantage Vue $300 \mathrm{~m}$ localizado ao lado do experimento e os dados médios durante a condução do experimento foram de 16,4 e $15,8^{\circ} \mathrm{C}$ para temperatura do ar, de 14,5 e 13,7 horas de umidade relativa do ar $\geq 90 \%$ e a precipitação pluvial acumulada foi de 572,5 e $502,7 \mathrm{~mm}$ respectivamente para 2019 e 2020.

Foi utilizado isolado de $P$. marginalis pv. marginalis isolado de folhas de alho e mutante a rifampicina $\left(\mathrm{Pmm}^{\mathrm{rf}}\right)$ obtida de colônia isolada em meio de cultura King-B contendo rifampicina $150 \mathrm{mg} / \mathrm{L}$ e plaqueada por três vezes consecutivas para manutenção da resistência a rifampicina. A finalidade da bactéria mutante é ser diferenciadora de outras bactérias florescentes que não são isoladas devido o meio ser especifico para esta.

Bulbilhos de alho do cv. "Chonan" foram microbiolizados por 5,5 horas (MARCUZZO 2002) em uma suspensão de $\mathrm{Pmm}^{\text {rf }}$ com 48 horas de crescimento preparada em solução salina $(\mathrm{NaCl} 0,85 \%)$, a uma concentração em espectrofotômetro de $\mathrm{OD}_{550}=0,5\left(1 \times 10^{9}\right.$ UFC.mL-1 $\mathrm{m}^{-1}$. Após esse período, a campo, foram semeadas em quatro canteiros contendo cada um 5 metros de comprimento por 1,25 m de largura. Em cada canteiro com cinco linhas foram semeados 250 bulbilhos, com espaçamento de 0,25 entre filas e 0,10 entre plantas. A calagem, adubação de plantio e de cobertura e os tratos culturais foram feitos conforme recomendação para a cultura (NICK \& BORÈM 2017, LUCINI 2004). Para os tratamentos fitossanitários,

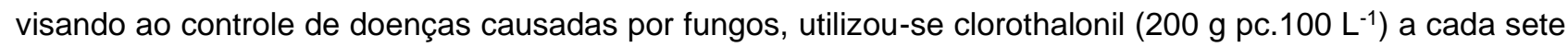
dias ou após a precipitação acumulada de $25 \mathrm{~mm}$. O clorotalonil não apresenta interferência sobre a bactéria em estudo (MARCUZZO 1999).

Quinze dias após o plantio até o final do ciclo da cultura coletou-se 3 folhas baixeiras de plantas aleatórias em cada canteiro nas filas centrais para levantamento da população epifítica. As folhas foram acondicionadas em caixa de isopor contendo gelo para a manutenção de temperatura durante o transporte até o laboratório. A avaliação da população epifítica de Pmmrf foi de quatro repetições contendo sub-amostra de um (1g) grama de folhas cortadas transversamente em torno de um centímetro e adicionadas em tubo de ensaio contendo $10 \mathrm{ml}$ de solução salina ( $\mathrm{NaCl}$ 0,85\%). A solução foi homogenizada com auxílio de um agitador de tubos durante 30 segundos e, em seguida, foi diluída em série até 10-10 e plaqueada com auxílio de alça de Drigalski em meio de cultura King-B acrescida de rifampicina a $150 \mathrm{mg} / \mathrm{L}$ e uma suspensão de 100 $\mu \mathrm{l}$ de Clorotalonil (1,3 g. $\left.\mathrm{L}^{-1}\right)$ espalhada em sua superfície para não ocorrer a proliferação de fungos e não interferir na bactéria (MARCUZZO \& JUBANSKI 2021, VANDERLINDE \& MARCUZZO 2019, MARCUZZO 1999). Após a incubação em câmara de crescimento tipo B.O.D (Biological Demand Oxigen) com temperatura de $28^{\circ} \mathrm{C}$ por 48 horas, as colônias de Pmmr foram contadas em câmara de luz negra para a observação da fluorescência emitida pela bactéria mutante isolada dos bulbilhos com e sem assepsia e expressa em UFC (unidade formadora de colônia). 
A avaliação da severidade da doença foi feita em 25 plantas centrais de cada canteiro previamente demarcadas, onde semanalmente após 15 dias do plantio avaliou-se a severidade total da planta através de escala diagramática proposta por MARCUZZO et al. (2021).

Para verificar a relação entre a flutuação epifítica bacteriana e a severidade da queima bacteriana durante o ciclo da cultura, os dados foram submetidos ao cálculo do coeficiente de correlação linear de Pearson ( $r$ ) e sua significância foi verificada valores críticos de correlação do teste. Em ambos os anos de avaliação, a correlação de Pearson ( $r$ ) entre o número de unidades formadoras de colônias e a severidade da doença foi significativa pelo teste à 1 e 5\% no ciclo de 2019 e 2020 respectivamente (Tabela 1). Entre os escassos trabalhos na área, JARDINE \& STEPHENS (1987) também verificam que a flutuação da população bacteriana de Pseudomonas syringae pv. tomato está associada com a ocorrência da doença em plantas de tomateiro no estado de Michigan nos Estados Unidos da América.

A coleta de colônias bacterianas nos anos de 2019 e 2020 ocorreu concomitante à constatação da doença a campo na $7^{\text {a }}$ semana após a semeadura (Tabela 1; Figura 1), mesmo tendo inoculado o bulbilho com a bactéria. MARCUZZO et al. (2009), apesar de coletar colônias de Xanthomonas spp. em tomateiro após 1 semanas do plantio, os sintomas só se evidenciaram após a população passar para $10^{5}$, efeito que também foi constatado em Pseudomonas syringae pv. tomato no tomateiro por JARDINE \& STEPHENS (1987). Neste trabalho não ocorreu, já que as bactérias foram inoculadas diretamente no bulbilho e não estavam presentes nas folhas na fase epifítica (MARCUZZO \& DENARDIM 2008, BEATTIE \& LINDOW 1995).

Tabela 1. Coeficiente de correlação ( $r$ ) entre o número de unidades formadoras de colônias (UFC) de Pseudomonas marginalis pv. marginalis coletadas semanalmente e as respectivas severidades da queima-bacteriana em 2019 e 2020. IFC, Campus de Rio do Sul, SC.

Table 1. Correlation coefficient ( $r$ ) between the number of colonies forming units (CFU) of Pseudomonas marginalis pv. marginalis collected weekly and the respective severity of bacterial blight in 2019 and 2020. IFC, Campus do Rio do Sul, SC.

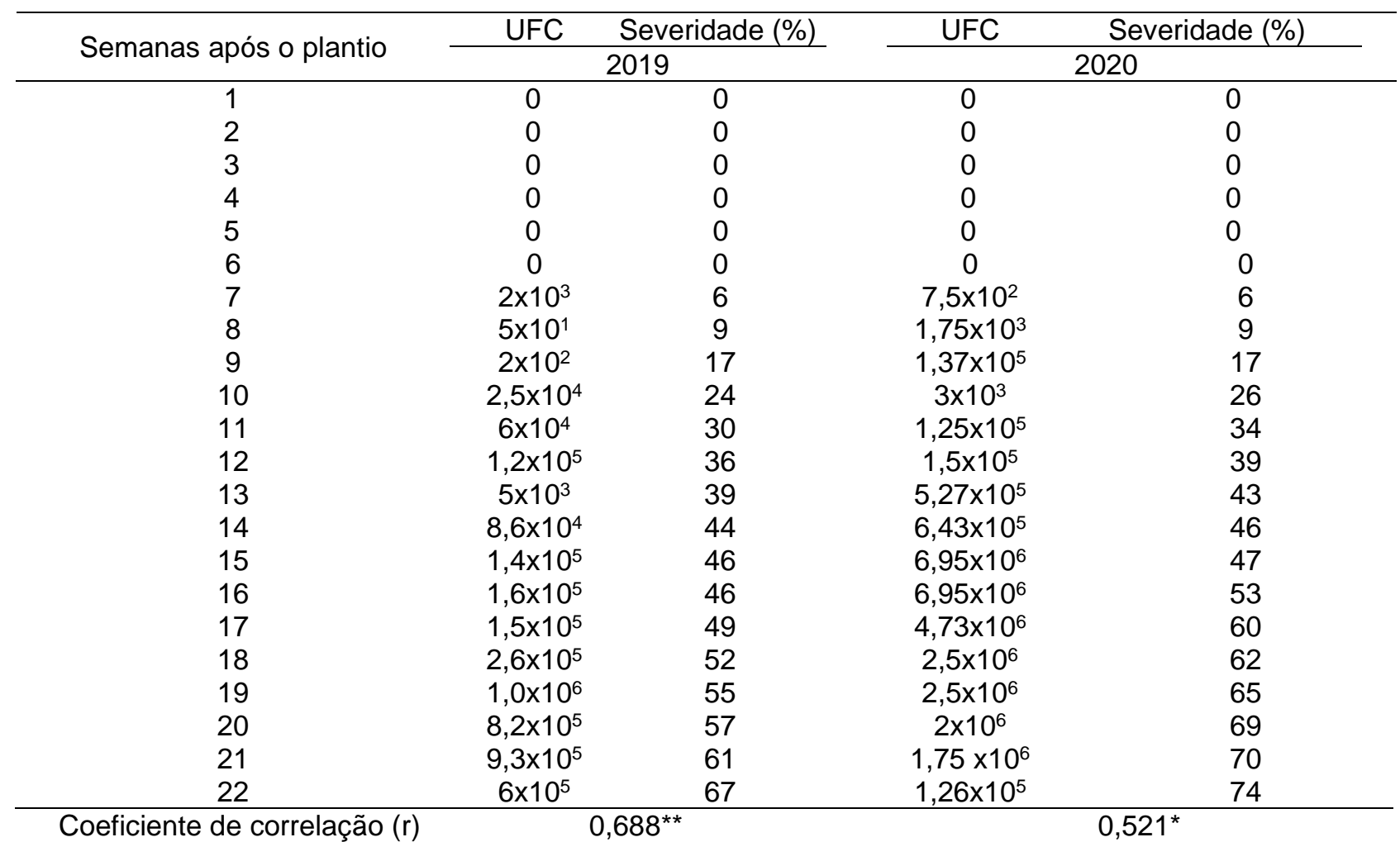

Significativo a $1 \%\left(^{* *}\right)$ e $5 \%\left(^{*}\right)$ de probabilidade pelo valor crítico do teste de correlação de Pearson.

Houve pouca oscilação no número de UFC em 2019 da 14 a 22ª semana permanecendo na escala de $10^{5}$ (Tabela 1), no entanto a severidade da doença foi mais acentuada a partir da $7^{\text {a }}$ semana e finalizando com $67 \%$, enquanto que em 2020 a população epifítica passou para $10^{6}$ a partir da $15^{\text {a }}$ semana (Figura 1). Isso se deve possivelmente a ocorrência de ferrugem causada por Puccinia porri na área, que fez com que a ruptura da cutícula foliar pelas pústulas, tornasse expostas as células bacterianas na superfície foliar e gerando mais inóculo para novas infecções com isso favorecendo o progresso da doença, bem como abertura no tecido vegetal para novas infecções da bactéria (Figura 1). 
Figura 1. Progresso da severidade da queima-bacteriana e da população epifítica de Pseudomonas marginalis pv. marginalis de alho cv. "Chonan" durante o ciclo da cultura. IFC/Campus Rio do Sul 2019-2020.

Figure 1. Progress in the severity of bacterial blight and the epiphytic population of Pseudomonas marginalis pv. marginalis of garlic cv. "Chonan" during the culture cycle. IFC/Campus Rio do Sul 2019-2020.

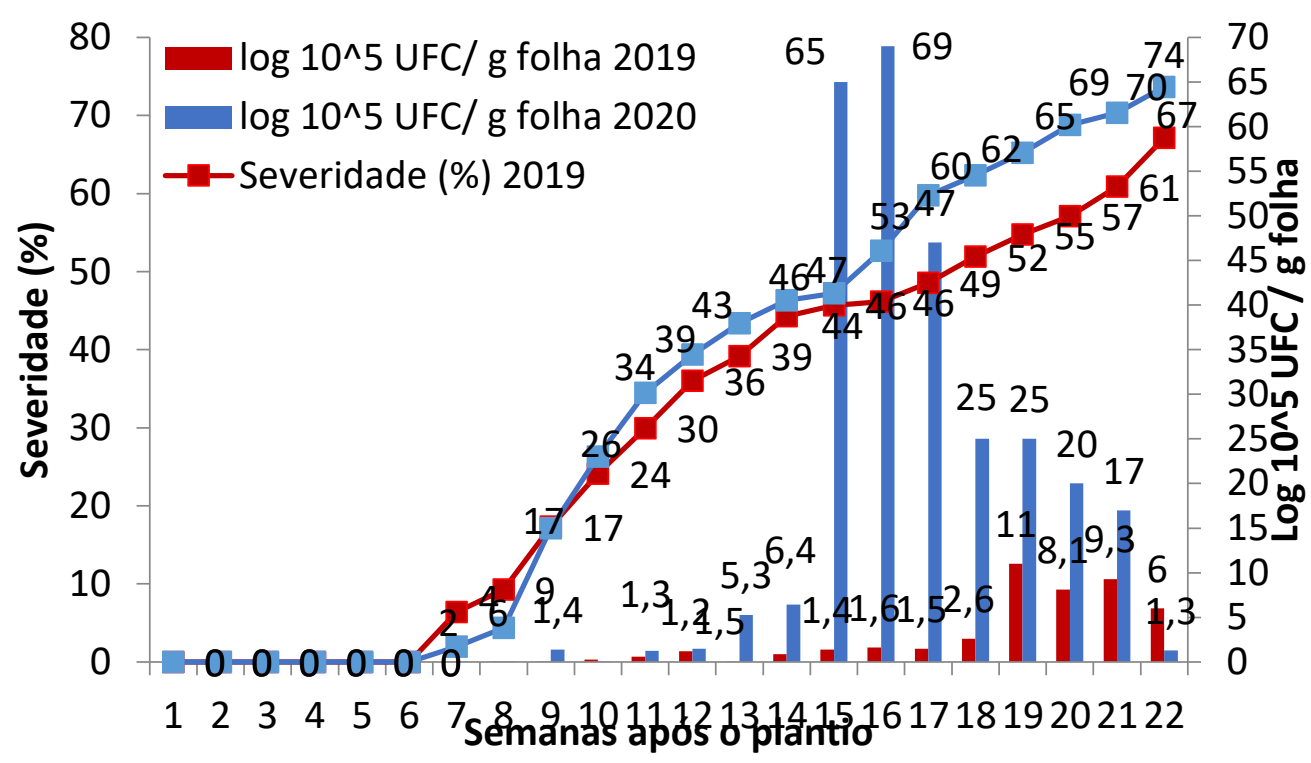

Após a sétima semana do aparecimento da doença no ano de 2019, observou-se um acréscimo gradual de severidade, que apesar do número de UFC coletados variou durante o período, ocorrendo seu pico na $19^{\mathrm{a}}$ semana e reduzindo-se nas duas semanas antes da colheita (Figura 1). Isso pode ser associado ao inóculo de que a planta já se encontrava em processo de senescência e também a grande taxa de infecção da queima bacteriana, o que resultou na diminuição do número de UFC coletadas. A correlação entre os dados da severidade da doença e da população epifítica coletada foi significativa, $r=0,688$, (Tabela 1 ) indicando moderada linearidade entre estas duas variáveis.

No ano de 2020, apesar de pouco variável o número de UFC entre a $18^{\mathrm{a}}$ e $22^{\mathrm{a}}$ semana após o plantio, verificou-se que a severidade da doença progrediu lentamente durante esse período (Figura 1). O número de UFC mais que dobrou a partir da $15^{\text {a }}$ semana, com exceção na última semana que teve redução devido senescência foliar, porém a doença foi gradativa durante esse período. A correlação $(r=0,521)$ entre a flutuação epifítica e a severidade da doença foi moderada e significativa no ano de 2020 (Tabela 1).

JARDINE \& STEPHENS (1987) avaliando a flutuação epifítica de Pseudomonas syringae pv. tomato, agente causal da pinta bacteriana do tomateiro observaram que foi constante a coleta durante o período vegetativo da cultura, similar ao que ocorreu nesse trabalho. Outro aspecto verificado nesse trabalho em que a maior concentração de colônias bacterianas ocorreu entre a 19a e $21^{\underline{a}}$ semana em 2019 e da $15^{\underline{a}}$ a $17^{\text {a }}$ em 2020, coincidindo com a fase de diferenciação e enchimento do bulbo, o que também foi verificado em Xanthomonas spp. na maturação dos primeiros frutos no tomateiro (MARCUZZO et al. 2009). Isso possivelmente é devido à translocação de fotoassimilados para o bulbo, em que as folhas baixeiras que estão em início de senescência, ocorre liberação desses compostos, inicialmente no interior das células dos tecidos foliares, seguido da disponibilização desses nutrientes para os espaços intercelulares, nos quais se encontram as bactérias, propiciando, aumento de sua população (MARCUZZO \& VIEIRA 2020, MARCUZZO \& DENARDIM 2008, BEATTIE \& LINDOW 1995). Isso evidência que o inóculo presente na superfície foliar serve de um indicativo para o aumento da ocorrência da doença (MARCUZZO \& CATAFESTA 2021, MARCUZZO 2009, HIRANO \& UPPER 1983, KIMURA 1981).

A presença de células bacteriana de $P$. marginalis pv. marginalis é um indicador do aumento da severidade da queima-bacteriana-do-alho e pode ser usado futuramente como um indicador de controle em um sistema de previsão da doença.

\section{AGRADECIMENTOS}

O presente trabalho foi realizado com apoio do Conselho Nacional de Desenvolvimento Científico e Tecnológico - Brasil (CNPq) pela concessão da bolsa iniciação cientifica PIBIC-Af edital 13/2019. 


\section{REFERÊNCIAS}

BEATTIE GA \& LINDOW SE. 1995. The secret life of foliar bacterial pathogens on leaves. Annual Review of Phytopathology 33: 145-172.

BECKER WF. 1991. Queima bacteriana do alho. Agropecuária Catarinense 4: 14-19.

BECKER WF. 2004. Doenças do alho: sintomatologia e controle. Florianópolis: Epagri.

BERGAMIM FILHO A \& AMORIM L. 2011. Epidemiologia de doenças de plantas. In: AMORIM L et al. (Ed.). Manual de fitopatologia: princípios e conceitos. São Paulo: Ceres. p.101-118.

EMBRAPA. 2013. Empresa Brasileira de Pesquisa Agropecuária. Sistema Brasileiro de classificação de solos. Brasília. DF: Embrapa.

HIRANO SS \& UPPER CD. 1983. Ecology and epidemiology of foliar bacterial plant pathogens. Annual Review of Phytopathology 21: 243-269.

JARDINE DJ \& STEPHENS CTA. 1987. Predictive system for timing Chemical applications to control Pseudomonas syringae pv. tomato, causal agent of bacterial speck. Phytopathology 77: 823-827.

KIMURA O. 1981. Importância das populações "residentes" de fitobactérias na epidemiologia de enfermidades bacteriana. Fitopatologia Brasileira 6: 310-311.

LOPES CA \& QUEZADO-SOARES AM. 1997. Doenças bacterianas das hortaliças: Diagnose e controle. Brasília: Embrapa CNPH.

LUCINI MA. 2004. Alho: manual prático de produção. Curitibanos: Bayer crop science.

MARCUZZO LL \& CATAFESTA A. 2021. Epidemiologia temporal da queima bacteriana do alho. Revista Agronomia Brasileira 5: 1-6.

MARCUZZO LL \& FÜCHTER D. 2021a. Influence of temperature and daily leaf wetness duration on the severity of bacterial leaf blight of garlic. Summa Phytopathologica 47: 180-182.

MARCUZZO LL \& FÜCHTER D. 2021b. Influência da temperatura e da duração do molhamento foliar na severidade da queima bacteriana do alho. Revista Agronomia Brasileira 5: 1-3.

MARCUZZO LL \& JUBANSKI M. 2021. Sobrevivência de Pseudomonas marginalis pv. marginalis em resíduo de alho no solo. Revista Agronomia Brasileira 5: 1-4.

MARCUZZO LL \& SANTOS L. 2021. Sobrevivência de Pseudomonas marginalis pv. marginalis do alho em plantasdaninhas. Revista Agronomia Brasileira 5: 1-5.

MARCUZZO LL \& AMLER DA. 2020. Sobrevivência de Pseudomonas marginalis pv. marginalis em bulbilhos de alho. Revista de Ciências Agroveterinárias 19: 498-501.

MARCUZZO LL \& VIEIRA C. 2020. Avaliação da sobrevivência de Pseudomonas marginalis pv.marginalis na palha durante o armazenamento de alho. Global Science and Technology 13:126-131.

MARCUZZO LL. 2018. Queima bacteriana em alho. Cultivar Hortaliças e Frutas 112: 5-7.

MARCUZZO LL. 2009. Importância das populações epifíticas na epidemiologia de enfermidades bacterianas. Revista de Ciências Agroveterinárias 8: 146-151.

MARCUZZO LL et al. 2021. Elaboração e validação de uma escala diagramática para a queima bacteriana do alho. Summa Phytopathologica 47: 183-186.

MARCUZZO LL et al. 2009. Alguns aspectos epidemiológicos da mancha bacteriana (Xanthomonas spp.) do tomateiro na região de Caçador/SC. Summa Phytopathologica 35: 132-135.

MARCUZZO LL \& DENARDIM ND. 2008. Colonização de bactérias causadoras de doenças foliares. Revista de Ciências Agroveterinárias 7: 169-176.

MARCUZZO LL. 2002. Seleção e caracterização biológica de bactérias com potencial para o controle biológico da queima bacteriana do alho. Dissertação (Mestrado em fitossanidade). Pelotas: UFPel. 52p.

MARCUZZO LL. 1999. Fitopatologia - Avaliação da Sensibilidade in vitro da Pseudomonas fluorescens (queima bacteriana), biovar II à bactericidas. Monografia (Graduação em agronomia). Lages: UDESC. 57p.

MOURA AB \& ROMEIRO RS. 1997. Garlic bulbils as biological baits for detection an diagnosis of Pseudomonas marginalis. Summa phytopathologica 23: 252-254

NICK C \& BORÉM A. 2017. Alho: do plantio a colheita. Viçosa: UFV.

ROMEIRO RS. 1995. Doenças causadas por bactérias em alho. Informe Agropecuário 17: 46-49.

SOUZA PE. 2009. Doenças do alho. In: SOUZA RJ \& MACEDO FS. (Ed.). Cultura do alho: tecnologias modernas de produção. Lavras: UFLA. p.109-126.

VANDERLINDE AH \& MARCUZZO LL. 2019. Sobrevivência de Pseudomonas marginalis pv. marginalis no solo, agente etiológico da queima bacteriana do alho. In: XX Feira do conhecimento científico e tecnológico, Rio do Sul. Resumos... Rio do Sul: IFC/Campus Rio do Sul. Disponível em: http://www.ifc-riodosul.edu.br/fetec/. Acesso em 10 nov. 2020. 